\title{
Addressing technology integration concerns: Asynchronous video mentoring between pre-service teachers and exemplary technology-using in-service teachers
}

\author{
Anne Todd Ottenbreit-Leftwich, Krista D. Glazewski, Thomas A. Brush \\ School of Education, Instructional Systems Department, Indiana University \\ Sinem Aslan \\ Adaptive Learning Project, Intel Corporation
}

Aaron Zachmeier

University of California, Santa Cruz

\begin{abstract}
Research has identified that pre-service teachers have concerns about technology integration (e.g., their future school would lack technology resources; technology is not applicable in their subject areas). Mentoring has been highlighted as a means of overcoming these concerns. In this study, we present and investigate one strategy - an asynchronous video mentoring session between a class of 199 pre-service teachers and four exemplary award-winning technology-using in-service teachers. A small group of the pre-service teachers $(n=31)$ voluntarily expressed their concerns. The four in-service teachers were videotaped as they responded to these concerns. All 199 pre-service teachers watched the videos and described how the in-service teachers' responses either alleviated or increased their concerns. A majority of the pre-service teachers (58\%) reported that their primary concerns regarding technology integration were less acute after they watched the teachers' presentation. Teacher education programs might consider the use of digital technologies to support student voices and increase the opportunities for interaction between pre-professionals and practising professionals.
\end{abstract}

\section{Inclusion of technology integration in teacher education programs}

In most classrooms in the United States, teachers and students have access to a wide variety of technology resources (e.g., laptops, tablets, video recorders, and interactive whiteboards) (Hall, 2010). According to a recent report conducted by the Pew Research Center (Lenhart, 2015), nearly 75\% of US teens have (or have access to) a smartphone. The availability of smartphones has increased dramatically (Project Tomorrow, 2013). Although only $24 \%$ in middle school and $28 \%$ in high school reported their availability to smartphones in 2008 , in 2012 these numbers jumped to $65 \%$ and $80 \%$ respectively. This increase followed a similar pattern for personal digital readers (from 17\% in 2011 to 39\% in 2012) and tablets (from 26\% in 2011 to 52\%) among middle school students (Project Tomorrow, 2013). However, this enormous increase in technology resources among students and teachers does not guarantee teachers' effective use of technology in classrooms (Ertmer \& Ottenbreit-Leftwich, 2010).

Technology preparation has become a common feature in teacher education programs (Ottenbreit-Leftwich et al., 2012), as teachers are expected to have sufficient technology skills (ISTE, 2014). However, several metaanalysis studies (Mims, Polly, Shepherd, \& Inan, 2006; Polly, Mims, Shepherd, \& Inan, 2010) have found mixed results as to whether technology coursework in teacher education programs improved pre-service teachers' technology skills or encouraged technology use in the classroom. Pellegrino, Goldman, Bertenthal, and Lawless (2007) suggested that this could result from lack of sufficient modelling of appropriate uses of technology in the classroom by teacher education faculty, and suggest it may be accompanied by the minimal exposure to appropriate uses of technology that pre-service teachers receive during their field experiences. In their meta-analysis of technology integration in teacher education programs, Polly et al. (2010) found that field experiences with teachers who integrated technology helped pre-service teachers develop positive technology attitudes, use technology more frequently and increase their uses of technology to support learning. However, they also found that a 'lack of technology-rich field experiences limited pre-service teachers' opportunities to 
learn' (p. 866) about technology integration in teaching and learning. Although many have indicated that field experiences are one of the most effective approaches for pre-service teachers, the implementation of field experiences can sometimes be impractical due to the number of pre-service teachers and the lack of in-service teachers using technology (Strudler \& Grove, 2002). Therefore, other approaches have been recommended, such as mentoring and modelling technology uses.

\section{Modelling and mentoring}

Research has identified that pre-service teachers have concerns about technology integration (e.g., their future school would lack technology resources; technology is not applicable in their subject areas; they are concerned about their own technology skills) (Cullen \& Greene, 2011; Hur, Shen, Kale, \& Cullen, 2015; Zhou, Zhang, \& $\mathrm{Li}, 2011$ ). Modelling and mentoring have been highlighted as a means of overcoming these concerns (Tharp \& Dirksen, 1996; Kim \& Baylor, 2008). In the meta-analysis of the 33 federally funded pre-service teacher technology grants, Mims et al. (2006) found that exposing pre-service teachers to strong models of technology use in the classroom could foster positive attitudes towards technology. Kim, Jain, Westhoff, and Rezabek (2008) surveyed 92 pre-service teachers enrolled in an educational technology class and also found that faculty modelling of technology use was associated with pre-service teachers' intentions to use technology.

Smarkola (2007) suggested that using in-service teachers as models or mentors may inform pre-service teachers about aspects of practice that pre-service teachers had not considered. Exemplary technology-using in-service teachers have experience with overcoming the concerns or barriers typically retained by pre-service teachers (Ertmer \& Ottenbreit-Leftwich, 2010). By describing their own experiences and strategies for overcoming the barriers, it may directly allay the concerns that pre-service teachers had about the use of technology in the classroom.

\section{Pre-service teachers' intentions to use technology}

There are several factors that have been identified as critical to pre-service teachers' intentions to use technology in their future classrooms. One of these is their attitudes towards technology. In a survey of 239 pre-service teachers enrolled at the National Institute of Education in Singapore, Teo, Lee, and Chai (2008) found that when pre-service teachers thought the technology was useful and easy to use, they were more likely to have positive attitudes about that technology. In addition, when pre-service teachers believed that they were expected to use a particular technology (e.g., an expectation that a math teacher use GeoGebra), they were more likely to perceive that the technology was useful.

Another predictor of pre-service teachers' intentions to use technology is their self-efficacy (Anderson \& Maninger, 2007; Teo et al., 2008). Self-efficacy is what an individual believes he or she is capable of doing (Bandura, 1997). Self-efficacy is an important factor in whether a teacher will use technology in the classroom. Even if teachers have knowledge of how to integrate technology, if they lack the belief that they are capable of integrating technology, they will not be able to use it (Ertmer, Conklin, \& Lewandowski, 2002; Ertmer \& Ottenbreit-Leftwich, 2010). This suggests that if pre-service teachers have low self-efficacy for technology use, they will be less likely to integrate technology into their teaching practices, even if they have the necessary skills.

Because self-efficacy represents a critical factor in pre-service teachers' intention to integrate technology, it is important to develop not only technology integration skills and knowledge during teacher education programs, but also to alleviate pre-service teachers' concerns and develop their feelings of self-efficacy. One method for doing this is through cases or vicarious experiences, which can build the observer's confidence and control, reduce anxiety and increase self-efficacy with a particular task (Jonassen \& Hernanadez-Serrrano, 2002; Kolodner, 1992; Oliver \& Shapiro, 1993). This is especially effective with teachers, as they typically learn through their own experiences or the vicarious experiences of others, as pointed by Hughes (2005) and Ertmer (2005). The assumption is that the stories and experiences of others can serve as artefacts that contribute to our own learning and may serve to bridge some of the gaps that exist between classroom-based learning and professional practice (Kolodner, Owensby, \& Guzdial, 2004). 
When it comes to technology integration, one commonly identified gap is between what pre-service teachers learn about technology in teacher education programs and how they are expected to use technology in their own classrooms when they become teachers (Kalota \& Hung, 2012; Ottenbreit-Leftwich et al., 2012; Pope, Hare, \& Howard, 2002). To address this gap, it is important for pre-service teachers to interact with in-service teachers who can model appropriate and realistic technology use. One of the ways that pre-service teachers interact with in-service teachers is in a student-teaching relationship. However, many pre-service teachers do not use technology or work closely with exemplary technology-using teachers during their student teaching (Grove, Strudler, \& Odell, 2004; Ottenbreit-Leftwich et al., 2012). Based on a large-scale review of strategies for teaching technology skills to pre-service teachers, Kay (2006) suggested that developmental support from an in-service teacher is an important condition for pre-service teachers' meaningful use of technology in their future classrooms. It is therefore crucial to understand more about strategies that can facilitate interaction between pre-service teachers and exemplary technology-using in-service teachers for the following purposes: (a) model appropriate technology use, (b) address concerns about technology integration, and (c) provide suggestions for effective use of technology to support learning.

In this study, we present and investigate one strategy for achieving these three purposes: an asynchronous video mentoring session between pre-service teachers and exemplary technology-using in-service teachers. We examine the outcomes of this discussion, based on the perceptions of pre-service teachers regarding their intentions to use technology in their future classrooms.

\section{Purpose and research questions}

The purpose of this study was to initiate and investigate the outcomes of a three-phase intervention between pre-service teachers and exemplary technology-using in-service teachers. The intervention consisted of an asynchronous video mentoring session between a class of 199 pre-service teachers and four exemplary awardwinning technology-using in-service teachers. A small group of the pre-service teachers $(n=31)$ voluntarily expressed their concerns. The four in-service teachers were videotaped as they responded to these concerns (asynchronous video mentoring session). All 199 pre-service teachers watched the videos and described how the in-service teachers' responses either alleviated or increased their concerns.

Three research questions guided the study:

(1) What concerns do pre-service teachers have about integrating technology into their own future classrooms?

(2) Do exemplary technology-using in-service teachers' video mentoring responses address the concerns of pre-service teachers regarding technology integration in their own future classrooms?

(3) How do the exemplary technology-using in-service teachers' video mentoring responses change preservice teachers' concerns regarding technology integration into their future classrooms?

\section{Methods}

\section{Research ethics statement}

All guidelines for research with human subjects were followed. No identity-revealing information has been used for students and the data are kept confidential for the purpose of this study with no access to public. Also, the researchers had no conflicts of interest in this study; the researchers were not teaching the course during the time the research was collected.

\section{Research context and design}

We implemented a single case study research design (Yin, 1994) to examine pre-service teachers' perceptions about technology integration in a technology integration course. The unit of analysis for the single case was the 
entire course. The course was a requirement in a teacher education program at a large US university. At the time of the data collection, 199 pre-service teachers were enrolled in 11 sections of the course.

As this study involved an asynchronous video mentoring session between pre-service teachers and exemplary technology-using in-service teachers, four in-service K-12 teachers were asked to participate in the discussion. These teachers had recently received an award for their ability to engage students in technology-enhanced inquiry-based learning; thus, they were considered exemplary technology-using in-service teachers. The selection of these teachers was based on purposeful (judgment) sampling (Fraenkel \& Wallen, 2008; Marshall, 1996) as such a group of in-service teachers could best model exemplary technology use and address pre-service teachers' concerns about technology integration based on their own experiences. All four in-service teachers taught at the high school level, although they gave many examples that also applied to younger students as well. Their subject areas were science, language arts, English and social studies.

\section{Data collection, analysis and description of the intervention}

The intervention consisted of three-stages where each stage informed the next. During these three stages, the intervention facilitated an asynchronous video mentoring session between 199 pre-service teachers and the four award-winning exemplary technology-using in-service teachers. The three stages of the intervention consisted of the following: (1) identify initial pre-service teachers' concerns, (2) in-service teachers respond to concerns, and (3) pre-service teachers review in-service teachers' responses and voice any new concerns.

Stage 1: Identify initial pre-service teachers' concerns.

An electronic questionnaire was created using an online questionnaire tool. The purpose of the questionnaire was to elicit pre-service teachers' concerns about technology integration. The five-item questionnaire consisted of two closed-ended demographic questions (subject area and grade level focus), two closed-ended questions on self-rated technology skills and self-rated interest in using technology in future classrooms and an openended question about the pre-service teachers' concerns related to technology integration. The questionnaire was pilot-tested with three pre-service teachers who had taken the same technology integration course in previous semesters. In these pilot tests, a 'think-aloud protocol' was implemented (Groves, Fowler, Couper, Lepkowski, \& Singer, 2009, p. 264). Researchers asked the participants to read the questions and options aloud and explain their thought process, including how they would answer each question and why. The instrument was tested and revised until the participants responded to our questions without any difficulty or misunderstanding.

Upon finalisation of the instrument, an email with a link to the voluntary questionnaire was sent to the 199 preservice teachers enrolled in the technology integration course. Thirty-one voluntarily responded to the questionnaire; this constituted a $16 \%$ response rate. The responses of these 31 pre-service teachers helped identify the initial concerns within the research tool. After the questionnaire data were collected, common concerns were identified using content analysis (these concerns would be used to initiative discussions with the exemplary technology-using in-service teachers in the next stage). Following the methods and guidelines suggested by Weber (1990), Krippendorff (2004) and Creswell (2009), a five-step content analysis procedure was implemented. Both inductive and deductive approaches to coding were used (Schadewitz \& Jachna, 2007). Two researchers (and previous instructors of the course) reviewed all data and coded separately. These researchers then met to discuss each coded data; where disagreements existed, they discussed them until coming to an agreement.

The open-ended question in the initial questionnaire was designed to elicit concerns: 'What concern(s) do you have in terms of barriers to the use of technology in your future classroom?' Content analysis of the initial questionnaire revealed that $61 \%$ of the respondents were concerned with resources (e.g., lack of money, equipment or time), 23\% with their own technology skills (e.g., insufficient skills and knowledge), 6\% with their subject area's perceived incompatibility with the use of technology, $6 \%$ with their own future students' attitudes towards or abilities with technology and $7 \%$ with other concerns (e.g., efficiency issues or obstructive school policy). 
Stage 2: In-service teachers respond to concerns

Pre-service teachers' common concerns about technology integration in their future classrooms were identified by analysing the questionnaire data using content analysis in the first stage. Based on the top four concerns that emerged, four questions were developed to guide the discussion and help the in-service teachers address the pre-service teachers' concerns from the first stage. These questions are listed below:

- Some pre-service teachers are concerned that their schools won't have enough money for technology resources. How would you address this concern? Do you face problems like this in your school? If so, what kinds of strategies have you and your school used to solve them?

- Some pre-service teachers are concerned that they do not have adequate technology skills. What are some of the ways that you have developed your technology skills as a teacher? What kinds of support are available to you as an educator?

- Some pre-service teachers are concerned that technology is not applicable to their subject area (especially math and language arts). Can you address this concern?

- Some pre-service teachers are concerned about their students' attitudes toward and abilities with technology. How do your students respond to technology? Do you feel that your students have adequate technology skills? How do you support their use of technology?

A panel discussion with the in-service teachers was organised. In this panel discussion, the teachers presented to a group of instructors who were teaching the technology integration course selected for this study to provide advice and mentorship on how to deal with these concerns. During the panel discussion, a moderator asked each question above and the in-service teachers responded with examples and advice. The in-service teachers addressed these four most common concerns of pre-service teachers regarding technology integration in their future classrooms. The panel mentoring discussion lasted approximately one hour. It was videorecorded and edited into cases for use in the next stage. Only the most relevant parts of the discussion were included in the cases. Table 1 provides a summary of how the in-service teachers addressed the specific concerns of pre-service teachers.

Table 1

Exemplary technology-using in-service teachers' responses to pre-service teachers' concerns

\section{Resources}

1. Seek donations of technology resources from parents and community organisations

2. Allow and ask students to bring their own technology to class

3. Establish trusting relationships with school administration, colleagues, and parents

4. Seek grant funding for technology resources

5. Be creative in finding ways to acquire technology resources

6. Look for unused or underused technology resources in your school

\section{Technology skills}

1. Join professional organisations for your subject area

2. Use unfamiliar technologies in low-risk situations

3. Read articles in your subject area

4. Attend conferences

5. Attend workshops offered by your district

6. Seek help from mentor teachers

7. Look for ways to refine and update your skills

8. Schedule time to learn about new technology resources

9. Establish goals for yourself

10. Implement new technology resources with a trial-and-error approach

11. Seek help from your students

12. Use social networking to connect with other teachers 


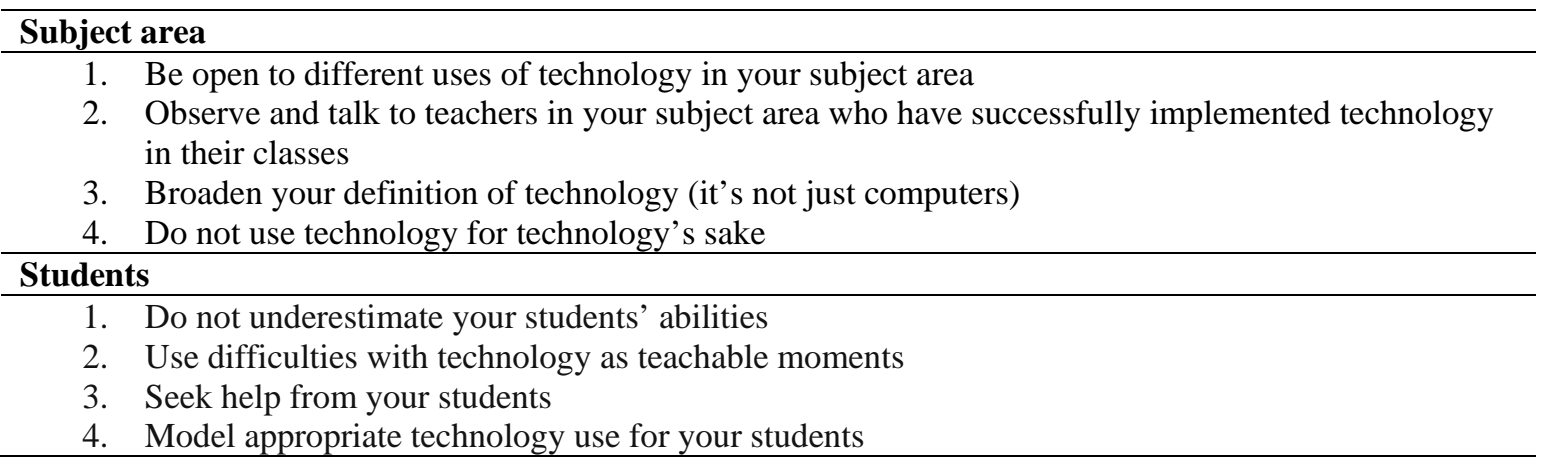

Stage 3: Pre-service teachers review in-service teachers' responses and voice any new concerns.

This stage was designed to examine the influence of the in-service teachers' presentation on the concerns of pre-service teachers regarding technology integration. An electronic questionnaire was designed to capture the data. A pilot-testing procedure (i.e., think-aloud protocol; Groves et al., 2009, p. 264) similar to that used for the initial questionnaire (again with three participants) was implemented to evaluate the construct validity of the questionnaire items. The instrument was revised multiple times using a similar approach to that used for the initial questionnaire.

The same group of 199 pre-service teachers enrolled in the technology integration course was invited to complete the questionnaire as a part of class preparation activity. Accompanying the questionnaire were four short video case presentations from the in-service teachers' panel; each video addressed one of the four questions from the discussion panel. In the 9-item follow-up questionnaire, the pre-service teachers were asked to select one of the four major concerns that emerged from the analysis of the initial questionnaire that they felt was their greatest concern. They watched the video of the exemplary technology-using in-service teachers addressing the concern they selected. They were then asked whether they thought their concerns were alleviated, aggravated or unaffected, and whether they had new concerns about technology integration.

One hundred eighty pre-service teachers completed the questionnaire as part of a class assignment, resulting in a 91\% response rate. Although the second questionnaire received a much higher response rate because it was part of a required class preparation activity for the technology integration course; it accounted for less than 1\% of the final course grade. This was the last of 15 homework assignments where pre-service teachers watched a video and then reflected on how they felt about technology, as well as their own growth. These homework assignments were all housed in the Canvas learning management system and used the questionnaire feature. Assignments typically take between 10 and 30 minutes. Students are encouraged to be reflective throughout the entire course and are not penalised on their responses as long as they are reflective and provide a rationale for why they are feeling this way. Of the total respondents (180) to the follow-up questionnaire, $65 \%$ (118) were in their first year (average age 18 years old); 23\% (41) were in their second year (19 years old); 9\% (16) were in their third year (20 years old); and 3\% (5) were in their fourth year (21 years old). The most common subject area concentrations were elementary education (33\%), special education (14\%), language arts (12\%) and social studies (12\%). We analysed both qualitative and quantitative questionnaire data using content analysis as described earlier and descriptive statistics.

\section{Results}

The primary purpose of this study was to examine how exemplary technology-using in-service teachers' expertise and modelling through electronic channels could address the concerns of pre-service teachers regarding technology integration in their own future classrooms. An analysis of the follow-up questionnaire data revealed the following: A majority of the pre-service teachers (58\%) were most concerned that their schools would not have enough money for technology resources. Some (19\%) were most concerned that technology would not be applicable in their subject areas, and others (13\%) were most concerned about their own 
technology skills. The least common concern was related to future students' attitudes towards or abilities with technology, with only $11 \%$ of the pre-service teachers identifying this as their primary concern.

In the remainder of this section, detailed results are presented for the following items: pre-service teachers' specific reasons for their concerns, level of concerns and any additional concerns that arose after viewing the in-service teachers' responses.

\section{Resources}

For those pre-service teachers who reported resources as their major concern, the follow-up questionnaire indicated that their major reasons were as follows: bad economic conditions (15\%), budgeting priorities (34\%), underfunded public schools (42\%) and underfunded private schools (5\%) (see Table 2).

Table 2

Themes/categories for concerns related to resources

\begin{tabular}{|c|c|c|}
\hline Themes/categories & $n(\%$ of 104) & Description of themes/categories \\
\hline \multicolumn{3}{|l|}{ Reasons $(n=104)$} \\
\hline Bad economic conditions & $16(15 \%)$ & $\begin{array}{l}\text { Prevailing economic conditions have led to school } \\
\text { budget cuts }\end{array}$ \\
\hline Budgeting priorities & 35 (34\%) & Technology is a low-priority item in school budgets \\
\hline Underfunded public schools & $44(42 \%)$ & $\begin{array}{l}\text { Public schools do not have sufficient funding for } \\
\text { technology }\end{array}$ \\
\hline Underfunded private schools & $5(5 \%)$ & $\begin{array}{l}\text { Private schools do not have sufficient funding for } \\
\text { technology }\end{array}$ \\
\hline Other & $4(4 \%)$ & \\
\hline \multicolumn{3}{|l|}{ Level of concern $(n=104)$} \\
\hline Less & $63(61 \%)$ & $\begin{array}{l}\text { Less concerned after the intervention (asynchronous } \\
\text { video) }\end{array}$ \\
\hline Same & $30(29 \%)$ & $\begin{array}{l}\text { Just as concerned after the intervention } \\
\text { (asynchronous video) }\end{array}$ \\
\hline More & $4(4 \%)$ & $\begin{array}{l}\text { More concerned after the intervention (asynchronous } \\
\text { video) }\end{array}$ \\
\hline Unclear & $7(7 \%)$ & Level of concern is unclear \\
\hline \multicolumn{3}{|l|}{ Additional concerns $(n=104)$} \\
\hline Yes & $47(45 \%)$ & $\begin{array}{l}\text { Additional concerns resulted from the intervention } \\
\text { (asynchronous video) }\end{array}$ \\
\hline No & $57(55 \%)$ & $\begin{array}{l}\text { No additional concerns resulted from the intervention } \\
\text { (asynchronous video) }\end{array}$ \\
\hline \multicolumn{3}{|c|}{ Types of additional concerns $(n=47)$} \\
\hline Administration & $16(34 \%)$ & $\begin{array}{l}\text { Administrators or school policy may present } \\
\text { obstacles to technology integration }\end{array}$ \\
\hline Donations & $4(9 \%)$ & $\begin{array}{l}\text { Some schools do not accept donations of technology } \\
\text { resources }\end{array}$ \\
\hline Grants & $12(26 \%)$ & Grant funding is difficult to obtain \\
\hline Resources & $4(9 \%)$ & $\begin{array}{l}\text { School budgets may not allow for the purchase of } \\
\text { technology resources }\end{array}$ \\
\hline Students & $6(13 \%)$ & $\begin{array}{l}\text { Students' skills and attitudes may present obstacles to } \\
\text { technology integration }\end{array}$ \\
\hline Technology skills & $4(9 \%)$ & $\begin{array}{l}\text { Pre-service teachers may not have sufficient skills for } \\
\text { technology integration }\end{array}$ \\
\hline Time & $1(2 \%)$ & $\begin{array}{l}\text { Pre-service teachers may not have sufficient time for } \\
\text { technology integration }\end{array}$ \\
\hline
\end{tabular}


One pre-service teacher explained her concern about the lack of resources in lower-income schools (where she would like to teach) in her open-ended response. She indicated this may make it difficult for her and her students to integrate technology:

Ideally, I would like to teach in an urban school setting with lower income students and families. For the most part, these families and the schools that are in their area are not properly funded. They do as much as they can with what they have. I am concerned that what they have is a serious lack of technology. The students that I will most likely be teaching will not have easy access to a computer or any type of device more technological. That would make it difficult for me to integrate technology into their everyday lives, with the absence of access. (Pre-service teacher 1 )

After viewing the in-service teachers' responses to their initial concerns, the majority of pre-service teachers (61\%) reported that they were less concerned about resources. About half of the pre-service teachers (45\%) indicated that they had new concerns. The majority indicated that their new concern was that administrators or school policy could present obstacles to technology integration.

\section{Subject area}

For those pre-service teachers that reported their subject areas as their major concern, the follow-up questionnaire indicated that their major reasons were as follows: grade level (32\%), lack of resources (9\%) and nature of subject (59\%) (see Table 3).

Table 3

Themes/categories for concerns related to subject area

\begin{tabular}{|c|c|c|}
\hline Themes/categories & $n(\%$ of 34$)$ & Description of themes/categories \\
\hline \multicolumn{3}{|l|}{ Reasons $(n=34)$} \\
\hline Grade level & $11(32 \%)$ & Technology may not be appropriate for some grade levels \\
\hline Lack of resources & $3(9 \%)$ & $\begin{array}{l}\text { School budgets may not allow for the purchase of } \\
\text { technology resources }\end{array}$ \\
\hline Nature of subject & $20(59 \%)$ & Some subject areas may not be compatible with technology \\
\hline \multicolumn{3}{|c|}{ Level of concern $(n=34)$} \\
\hline Less & $13(38 \%)$ & Less concerned after the intervention (asynchronous video) \\
\hline Same & 18 (53\%) & $\begin{array}{l}\text { Just as concerned after the intervention (asynchronous } \\
\text { video) }\end{array}$ \\
\hline More & $1(3 \%)$ & $\begin{array}{l}\text { More concerned after the intervention (asynchronous } \\
\text { video) }\end{array}$ \\
\hline Unclear & $2(6 \%)$ & Level of concern is unclear \\
\hline \multicolumn{3}{|c|}{ Additional concerns $(n=34)$} \\
\hline Yes & $12(35 \%)$ & $\begin{array}{l}\text { Additional concerns resulted from the intervention } \\
\text { (asynchronous video) }\end{array}$ \\
\hline No & $22(65 \%)$ & $\begin{array}{l}\text { No additional concerns resulted from the intervention } \\
\text { (asynchronous video) }\end{array}$ \\
\hline \multicolumn{3}{|c|}{ Types of emerging concerns $(n=12)$} \\
\hline Parents & $4(33 \%)$ & Parents may present an obstacle to technology integration \\
\hline Resources & $3(25 \%)$ & $\begin{array}{l}\text { School budgets may not allow for the purchase of } \\
\text { technology resources }\end{array}$ \\
\hline Students & $2(17 \%)$ & $\begin{array}{l}\text { Students' skills and attitudes may present obstacles to } \\
\text { technology integration }\end{array}$ \\
\hline Technology skills & $1(8 \%)$ & $\begin{array}{l}\text { Teachers may not have sufficient skills for technology } \\
\text { integration }\end{array}$ \\
\hline Other & $2(17 \%)$ & \\
\hline
\end{tabular}


One future physical education teacher described how he perceived that technology lacked applicability in his subject area of physical education in his open-ended response:

I was most concerned that technology is not applicable to my subject area because my subject area is physical education. I am aware that there are technologies that can apply to my subject area, but it is limited. I wish there were more resources available for physical education. (Preservice teacher 2)

After viewing the in-service teachers' video responses to their initial concerns, $38 \%$ of the pre-service teachers reported that they were less concerned about the perceived incompatibility of their subject area with technology. Some pre-service teachers (35\%) indicated that they had new concerns. The majority reported that their new concern was that parents may present an obstacle to technology integration.

\section{Technology skills}

For the pre-service teachers who reported their own technology skills as their major concern, the follow-up questionnaire indicated that their major reasons were as follows: change in technology (39\%), low self-efficacy (39\%), negative attitude towards technology (17\%) and too much to learn (4\%) (see Table 4).

Table 4

Themes/categories for concerns related to technology skills

\begin{tabular}{|c|c|c|}
\hline Themes/categories & $n(\%$ of 23$)$ & Description of themes/categories \\
\hline \multicolumn{3}{|l|}{ Reasons $(n=23)$} \\
\hline Change in technology & $9(39 \%)$ & $\begin{array}{l}\text { It is too difficult to keep up with rapid changes in } \\
\text { technology }\end{array}$ \\
\hline Low self-efficacy & $9(39 \%)$ & $\begin{array}{l}\text { Pre-service teachers do not believe they are capable of } \\
\text { working with technology }\end{array}$ \\
\hline Negative attitude & $4(17 \%)$ & Pre-service teachers do not want to use technology \\
\hline Too much to learn & $1(4 \%)$ & $\begin{array}{l}\text { It is impossible to master all there is to know about } \\
\text { technology use }\end{array}$ \\
\hline \multicolumn{3}{|l|}{ Level of concern $(n=23)$} \\
\hline Less & $16(70 \%)$ & Less concerned after the intervention (asynchronous video) \\
\hline Same & $6(26 \%)$ & $\begin{array}{l}\text { Just as concerned after the intervention (asynchronous } \\
\text { video) }\end{array}$ \\
\hline More & $0(0 \%)$ & $\begin{array}{l}\text { More concerned after the intervention (asynchronous } \\
\text { video) }\end{array}$ \\
\hline Unclear & $1(4 \%)$ & Level of concern is unclear \\
\hline \multicolumn{3}{|c|}{ Additional concerns $(n=23)$} \\
\hline Yes & $9(39 \%)$ & $\begin{array}{l}\text { Additional concerns resulted from the intervention } \\
\text { (asynchronous video) }\end{array}$ \\
\hline No & $14(61 \%)$ & $\begin{array}{l}\text { No additional concerns resulted from the intervention } \\
\text { (asynchronous video) }\end{array}$ \\
\hline \multicolumn{3}{|c|}{ Types of emerging concerns $(n=9)$} \\
\hline Resources & $1(11 \%)$ & $\begin{array}{l}\text { School budgets may not allow for the purchase of } \\
\text { technology resources }\end{array}$ \\
\hline Students & $2(22 \%)$ & $\begin{array}{l}\text { Students' skills and attitudes may present obstacles to } \\
\text { technology integration }\end{array}$ \\
\hline Subject area & $1(11 \%)$ & Some subject areas may not be compatible with technology \\
\hline Technology skills & $1(11 \%)$ & $\begin{array}{l}\text { Teachers may not have sufficient skills for technology } \\
\text { integration }\end{array}$ \\
\hline Time & $4(44 \%)$ & $\begin{array}{l}\text { Teachers may not have sufficient time for technology } \\
\text { integration }\end{array}$ \\
\hline
\end{tabular}


One pre-service teacher described how although her current skills are up to date, she feels this may quickly change, and her students may eventually have more technology skills than she does:

I am concerned that I will not have adequate technology skills because technology is always changing. I think I am very tech savvy now; however, everything I know will eventually be outdated. Just how I think that I know more about technology now than my teachers, I think my students will know more about technology than me. (Pre-service teacher 3)

After viewing the in-service teachers' video responses to their initial concerns, the majority of pre-service teachers $(70 \%)$ reported that they were less concerned about their own technology skills. Some of the preservice teachers (39\%) indicated that they had new concerns. The majority reported that their new concern was that they may not have sufficient time for technology integration.

\section{Students}

For the pre-service teachers who reported their future students as their major concern, the follow-up questionnaire indicated that their major reasons were as follows: student age (11\%), distraction (32\%), mental abilities (11\%), resistance (32\%) and skills (11\%) (see Table 5). For example, one pre-service teacher described his doubt that technology could maintain all students' interest and engagement:

Every student is different. Coming from different backgrounds and opportunities, I know that each student will have had different experiences with technology. I think that students find technology interesting and fun, however, I know they can also be very distracted by it. While incorporating technology and ensuring everyone gets equal opportunity, I would like to make sure students don't find it boring or distracting. (Pre-service teacher 4)

After viewing the in-service teachers' video responses to their initial concerns, the majority of pre-service teachers $(68 \%)$ reported that they were less concerned about their future students with regard to technology integration. Some of the pre-service teachers (32\%) indicated that they had new concerns. The majority reported that their new concern was that their students' skills and attitudes may still present obstacles to technology integration.

Table 5

Themes/categories for concerns related to students

\begin{tabular}{|c|c|c|}
\hline Themes/categories & $\begin{array}{l}n \quad(\% \text { of } \\
19)\end{array}$ & Description of themes/categories \\
\hline \multicolumn{3}{|l|}{ Reasons $(n=19)$} \\
\hline Age & $2(11 \%)$ & Technology may not be appropriate for certain ages \\
\hline Distraction & $6(32 \%)$ & Students will be distracted by technology \\
\hline Mental abilities & $2(11 \%)$ & $\begin{array}{l}\text { Students will not have sufficient mental ability for technology } \\
\text { use }\end{array}$ \\
\hline Resistance & $6(32 \%)$ & Students will resist technology \\
\hline Skills & $2(11 \%)$ & $\begin{array}{l}\text { Students' skills and attitudes may present obstacles to } \\
\text { technology integration }\end{array}$ \\
\hline Other & $1(5 \%)$ & \\
\hline \multicolumn{3}{|c|}{ Level of concern $(n=19)$} \\
\hline Less & $13(68 \%)$ & Less concerned after the intervention (asynchronous video) \\
\hline Same & $5(26 \%)$ & Just as concerned after the intervention (asynchronous video) \\
\hline More & $0(0 \%)$ & More concerned after the intervention (asynchronous video) \\
\hline Unclear & $1(5 \%)$ & Level of concern is unclear \\
\hline
\end{tabular}




\begin{tabular}{lrl}
\hline $\begin{array}{l}\text { Emerging concerns }(n=19) \\
\text { Yes }\end{array}$ & $6(32 \%)$ & $\begin{array}{l}\text { Additional concerns resulted from the intervention } \\
\text { (asynchronous video) } \\
\text { No additional concerns resulted from the intervention } \\
\text { (asynchronous video) }\end{array}$ \\
$\begin{array}{l}\text { Types of emerging concerns }(n=6) \\
\text { Students } \\
5(83 \%)\end{array}$ & $\begin{array}{l}\text { Students' skills and attitudes may present obstacles to } \\
\text { technology integration } \\
\text { Teachers may not have sufficient skills for technology } \\
\text { integration }\end{array}$ \\
\hline
\end{tabular}

\section{Discussion}

The initial questionnaire with pre-service teachers revealed the four major concerns regarding technology integration in their future classrooms: resources, technology skills, subject area and students. In a videorecorded panel discussion, exemplary technology-using in-service teachers addressed these four major concerns of preservice teachers by providing suggestions and examples based on their experiences. These suggestions ranged from seeking donations of technology resources to seeking help from mentor teachers for improving technology skills.

In the follow-up questionnaire, we asked pre-service teachers to choose one of these four major concerns that was most salient to them. Results indicated that majority of the pre-service teachers (58\%) were most concerned with the fact that they would not have enough technology resources in their schools. Nineteen percent of preservice teachers indicated that their subject areas were not compatible with technology implementation, while $13 \%$ of them pointed out that they would not have enough technology knowledge and skills to implement it successfully. Eleven percent of pre-service teachers indicated that they were most concerned with students' attitudes towards or skills with technology. After watching exemplary technology-using teachers' presentation, a majority of the pre-service teachers (58\%) indicated that their concerns about technology integration were less acute.

\section{Implications for practice}

Research has indicated that pre-service teachers have concerns about technology integration (Cullen \& Greene, 2011; Hur et al., 2015; Zhou, Zhang, \& Li, 2011). The results of this study identified four major concerns of pre-service teachers involved in this study: resources, technology skills, subject area and students. Mims et al. (2006) pointed out importance of coaching teachers for using various technology resources in classrooms and revealed that this kind of support should come from 'individuals who are, at a minimum, committed to technology integration and preferably have mastered the technology in question' (p. 22). In line with this argument, Tharp and Dirksen (1996) and Kim and Baylor (2008) indicated that coaching and modelling are important for overcoming any concerns that pre-service teachers might have about technology integration, thus enabling them make effective technology integration decisions later. After viewing the in-service teachers' video responses to their initial concerns, a majority of the pre-service teachers (58\%) reported that their primary concerns regarding technology integration were less acute. As an efficient method for engaging pre-service teachers and exemplary technology-using in-service teachers in an intellectual conversation, teacher education programs may consider creating similar asynchronous video mentoring sessions and seek additional ways to expand on the conversations between pre-service and in-service teachers about technology.

Soldat (2009) investigated the evolution of teacher beliefs and identified teacher education programs as an important factor affecting such beliefs. Similarly, Pajares (1992) stated that 'educational beliefs of preservice teachers play a pivotal role in their acquisition and interpretation of knowledge and subsequent teaching behavior and that unexplored entering beliefs may be responsible for the perpetuation of antiquated and ineffectual teaching practices' (p. 328). Therefore, pre-service teachers' beliefs about technology use may impact their technology integration decisions as in-service teachers. To positively impact such beliefs in their 
teacher education programs, expert advice - one from an experienced in-service teacher - in technology integration is valuable, as pointed out earlier. However, in teacher education programs, it is difficult to have access to an in-service teacher who is able to model best practices in technology integration (Grove et al., 2004). The asynchronous video mentoring session we facilitated in this study may be one strategy that could provide pre-service teachers with more access to exemplary technology-using in-service teachers. Teacher education programs should consider the use of such connections to increase the opportunities for interaction between preservice teachers and in-service teachers.

An additional strategy that we are currently exploring is the use of rich video cases that capture the teaching practices of exemplary technology-using teachers (Brush \& Saye, 2009; Brush \& Saye, 2014; Callahan, Saye, \& Brush, 2014). These cases can be used to provide pre-service teachers with multiple examples of effective teaching practices even if they are unable to physically observe those practices in actual classrooms. We have found that the use of these cases can serve as a catalyst for discussions between faculty and pre-service teachers regarding effective uses of technology to support teaching and learning. Furthermore, the cases can provide pre-service teachers with a framework for further exploration of technology use in classrooms once they have opportunities to observe authentic classroom activities and engage in field-based teaching activities during their teacher education programs.

Engaging in the virtual cases may address some of the second-order barriers identified by Ertmer (1999), which are composed of teachers' beliefs about teaching and learning. Ertmer contrasted these with first-order barriers, which are extrinsic obstacles and resources. Dede (1998) and Fisher et al. (1996) (cited in Ertmer, 2009) noted that the forms of second-order barriers result in more challenges than first-order barriers as they relate to teachers' personal beliefs. One of the goals of the intervention implemented in this study was to expose preservice teachers to the realities of practice so as to impact their beliefs about technology integration. To promote belief change among teachers, Kagan (1992) revealed that a teacher education program or a professional development program should 'require them to make their preexisting personal beliefs explicit; ... challenge the adequacy of those beliefs, and ... give novices extended opportunities to examine, elaborate, and integrate new information into their existing belief systems’ (p. 77). Many of the pre-service teachers who participated in the study had new concerns about technology integration after viewing the in-service teachers' responses to their initial concerns as they were able to have a clearer and more complex picture of the realities of technology integration, challenge their beliefs about their concerns and elaborate on new concerns as an outcome of this learning experience. Teacher education programs can consider building similar channels between in-service teachers and pre-service teachers to enable belief change through similar asynchronous videos.

\section{Summary and conclusion}

In this study, we observed that facilitating an asynchronous video mentoring session between pre-service teachers and exemplary technology-using in-service teachers has the potential to reduce the concerns of preservice teachers about technology integration. This type of interaction is particularly important since such concerns are more likely to affect pre-service teachers' decisions about technology integration in their future classrooms. Finally, we note that not only are these types of mentoring exchanges and asynchronous videos possible, they are scalable across a variety of other university contexts. Technology now enables pre-service and in-service professionals to have a wide range of virtual interactions, most of which were not possible even a few short years ago. As it is rather difficult to have access to many exemplary technology-using in-service teachers in teacher education programs, such innovative strategies can help build stronger interactions between novices and experts on technology integration by directly serving as a model of what is possible.

\section{References}

Anderson, S. E., \& Maninger, R. M. (2007). Preservice teachers’ abilities, beliefs, and intentions regarding technology integration. Journal of Educational Computing Research, 37(2), 151-172. doi:10.2190/H1M8562W-18J1-634P

Bandura, A. (1997). Self-efficacy: The exercise of control. New York, NY: Freeman. 
Brush, T., \& Saye, J. (2014). An instructional model to support problem-based historical inquiry: The persistent issues in history network. Interdisciplinary Journal of Problem-Based Learning, 8(1), 3. doi:10.7771/1541-5015.1409

Brush, T., \& Saye, J. W. (2009). Strategies for preparing preservice social studies teachers to integrate technology effectively: Models and practices. Contemporary Issues in Technology and Teacher Education, 9(1), 46-59. Retrieved from http://www.citejournal.org/volume-9/issue-1-09/socialstudies/strategies-for-preparing-preservice-social-studies-teachers-to-integrate-technology-effectivelymodels-and-practices/

Callahan, C., Saye, J., \& Brush, T. (2014). Social studies teachers' interactions with second generation webbased educative curriculum. The Journal of Social Studies Research, 38(3), 129-141. doi:10.1016/j.jssr.2014.03.002

Creswell, J. (2009). Research design: Qualitative, quantitative, and mixed methods approaches (3rd ed.). Thousand Oaks, CA: Sage.

Cullen, T., \& Greene, B. (2011). Preservice teachers' beliefs, attitudes, and motivation about technology integration. Journal of Educational Computing Research, 45(1), 29-47. doi:10.2190/EC.45.1.b

Ertmer, P. A. (1999). Addressing first-and second-order barriers to change: Strategies for technology integration. Educational Technology Research and Development, 47(4), 47-61. doi:10.1007/BF02299597

Ertmer, P. A. (2005). Teacher pedagogical beliefs: The final frontier in our quest for technology integration? Educational Technology Research and Development, 53(4), 25-39. doi:10.1007/BF02504683

Ertmer, P. A., Conklin, D., \& Lewandowski, J. (2002). Using electronic models to increase preservice teachers' ideas and confidence for technology integration. In D. Willis, J. Price \& N. Davis (Eds.), Proceedings of Society for Information Technology \& Teacher Education International Conference 2002 (pp. 1314-1318). Chesapeake, VA: AACE. Retrieved from https://www.learntechlib.org/p/6716/

Ertmer, P. A., \& Ottenbreit-Leftwich, A. T. (2010). Teacher technology change: How knowledge, confidence, beliefs, and culture intersect. Journal of Research on Technology in Education, 42(3), 255-284. doi:10.1080/15391523.2010.10782551

Fraenkel, J. R., \& Wallen, N. E. (2008). How to design and evaluate research in education (7th ed.). New York, NY: McGraw-Hill.

Grove, K., Strudler, N., \& Odell, S. (2004). Mentoring toward technology use: Cooperating teacher practice in supporting student teachers. Journal of Research on Technology in Education, 37(1), 85-109. doi:10.1080/15391523.2004.10782427

Groves, R. M., Fowler, F. J., Couper, M. P., Lepkowski, J. M., \& Singer, E. (2009). Survey methodology (2nd ed.). Hoboken, NJ: John Wiley \& Sons.

Hall, G. E. (2010), Technology’s Achilles heel: Achieving high-quality implementation. Journal of Research on Technology in Education, 42(3), 231-253. doi:10.1080/15391523.2010.10782550

Harris, J. (2005). Our agenda for technology integration: It's time to choose. Contemporary Issues in Technology and Teacher Education, 5(2), 116-122. http://www.citejournal.org/volume-5/issue-205/editorial/our-agenda-for-technology-integration-its-time-to-choose/

Hughes, J. (2005). The role of teacher knowledge and learning experiences in forming technology-integrated pedagogy. Journal of Technology and Teacher Education, 13(2), 277-302. Retrieved from https://www.aace.org/pubs/jtate/

Hur, J. W., Shen, Y. W., Kale, U., \& Cullen, T. A. (2015). An exploration of pre-service teachers intention to use mobile devices for teaching. International Journal of Mobile and Blended Learning, 7(3), 1-17. doi:10.4018/ijmbl.2015070101

ISTE. (2014). ISTE standards for teachers' resources. Retrieved from https://www.iste.org/standards/standards-for-teachers

Jonassen, D. H., \& Hernandez-Serrano, J. (2002). Case-based reasoning and instructional design: Using stories to support problem solving. Educational Technology Research and Development, 50(2), 65-77. doi:10.1007/BF02504994

Kagan, D. M. (1992). Implications of research on teacher belief. Educational Psychologist, 27(1), 65-90. doi:10.1207/s15326985ep2701_6 
Kalota, F., \& Hung, W. C. (2012). Instructional effects of a performance support system designed to guide preservice teachers in developing technology integration strategies. British Journal of Educational Technology. Advance online publication. doi:10.1111/j.1467-8535.2012.01318.x

Kay, R. H. (2006). Evaluating strategies used to incorporate technology into preservice education: A review of the literature. Journal of Research on Technology in Education, 38(4), 383-408. doi:10.1080/15391523.2006.10782466

Kim. C., \& Baylor, A. L. (2008). A virtual change agent: Motivating pre-service teachers to integrate technology in their future classrooms. Educational Technology \& Society, 11(2), 309-321. http://www.jstor.org/stable/jeductechsoci.11.2.309

Kim, K., Jain, S., Westhoff, G., \& Rezabek, L. (2008). A quantitative exploration of preservice teachers' intent to use computer-based technology. Journal of Instructional Psychology, 35 (3), 275-287. Retrieved from http://www.projectinnovation.biz/jip_2006.html

Kolodner, J. L. (1992). An introduction to case-based reasoning. Artificial Intelligence Review, 6(1), 3-34. doi:10.1007/BF00155578

Kolodner, J. L., Owensby, J. N., \& Guzdial, M. (2004). Case-based learning aids. In D. H. Jonassen (Ed.), Handbook of research for educational communications and technology (2nd ed., pp. 829-861). Mahwah, NJ: Erlbaum.

Krippendorff, K. (2004). Content analysis: An introduction to its methodology (2nd ed.). Thousand Oaks, CA: Sage.

Lenhart, A. (2015, April 9). Teens, social media, \& technology overview. Washington, DC: Pew Research Center. Retrieved from http://www.pewinternet.org/2015/04/09/teens-social-media-technology-2015

Marshall, M. N. (1996). Sampling for qualitative research. Family Practice, 13(6), 522-526. doi:10.1093/fampra/13.6.522

Mims, C., Polly, D, Shepherd, C., \& Inan, F. (2006). Examining PT3 projects designed to improve preservice education. TechTrends, 50(3), 16-24. doi:10.1007/s11528-006-7599-5

Oliver, T.A., \& Shapiro, F. (1993). Self-efficacy and computers. Journal of Computer Based Instruction, 20(3), 81-85. Retrieved from http://dl.acm.org/citation.cfm?id=J444

Ottenbreit-Leftwich, A. T., Brush, T. A., Strycker, J., Gronseth, S., Roman, T., Abaci, S., ... \& Plucker, J. (2012). Preparation versus practice: How do teacher education programs and practicing teachers align in their use of technology to support teaching and learning? Computers \& Education, 59(2), 399-411. doi:10.1016/j.compedu.2012.01.014

Pajares, M. F. (1992). Teachers' beliefs and educational research: Cleaning up a messy construct. Review of educational research, 62(3), 307-332. doi:10.3102/00346543062003307

Pellegrino, J. W., Goldman, S. R., Bertenthal, M., \& Lawless, K. (2007). Teacher education and technology: Initial results from the "What Works and Why" project. Yearbook of the National Society for the Study of Education, 106(2), 52-86. doi:10.1111/j.1744-7984.2007.00115.x

Polly, D., Mims, C., Shepherd, C. E., \& Inan, F. (2010). Evidence of impact: Transforming teacher education with preparing tomorrow's teachers to teach with technology (PT3) grants. Teaching and Teacher Education, 26(4), 863-870. doi:10.1016/j.tate.2009.10.024

Pope, M., Hare, D., \& Howard, E. (2002). Technology integration: Closing the gap between what preservice teachers are taught to do and what they can do. Journal of Technology and Teacher Education, 10(2), 191203. Retrieved from http://learntechlib.org/p/15108/

Project Tomorrow. (2013). From chalkboards to tablets: The emergence of the K-12 digital learner. Retrieved from http://www.tomorrow.org/speakup/pdfs/SU12-Students.pdf

Schadewitz, N., \& Jachna, T. (2007). Comparing inductive and deductive methodologies for design patterns identification and articulation. In Proceedings of the International Association of Societies of Design Research Conference. Retrieved from http://www.sd.polyu.edu.hk/iasdr/proceeding/papers/Comparing Inductive and Deductive Methodologies for Design Patterns Identification.pdf

Smarkola, C. (2007). Efficacy of a planned behavior model: Beliefs that contribute to computer usage intentions of student teachers and experienced teachers. Computers in Human Behavior, 24(3), 1196-1215. doi:10.1016/j.chb.2007.04.005

Soldat, C. S. (2009). Investigating the impact of a preservice program on beliefs about science teaching and learning (Doctoral dissertation). Theses and Dissertations, 438. Retrieved from http://ir.uiowa.edu/etd/438/ 
Strudler, N., \& Grove, K. J. (2002). Integrating technology into teacher candidates’ field experiences: A twopronged approach. Journal of Computing in Teacher Education, 19(2), 33-39. doi:10.1080/10402454.2002.10784459

Teo, T., Lee, C.B., \& Chai, C.S. (2008). Understanding pre-service teachers' computer attitudes: Applying and extending the technology acceptance model. Journal of Computer Assisted Learning, 24(2), 128-143. doi:10.1111/j.1365-2729.2007.00247.x

Tharp, D., \& Dirksen, D.(1996). Utilizing Cbam to assess the use of instructional technologies in the classroom. In B. Robin, J. Price, J. Willis \& D. Willis (Eds.), Proceedings of Society for Information Technology \& Teacher Education International Conference 1996 (pp. 407-410). Chesapeake, VA: AACE. Retrieved from https://www.learntechlib.org/p/46815/

Weber, R. P. (1990). Basic content analysis. Newbury Park, CA: Sage. doi:10.4135/9781412983488

Yin, R. K. (1994). Case study research: Design and methods. Beverly Hills, CA: Sage.

Zhou, G., Zhang, Z., \& Li, Y. (2011). Are secondary preservice teachers well prepared to teach with technology? A case study from China. Australasian Journal of Educational Technology, 27(6), 943-960. $\underline{\text { doi:10.14742/ajet.922 }}$

Corresponding author: Anne Todd Ottenbreit-Lefwich, aleftwic@indiana.edu

Australasian Journal of Educational Technology @ 2018.

Please cite as: Ottenbreit-Leftwich, A., Glazewski, K., Brush, T., Aslan, S., \& Zachmeier, A. (2018). Addressing technology integration concerns: Asynchronous video mentoring between pre-service teachers and exemplary technology-using in-service teachers. Australasian Journal of Educational Technology, 34(4), 1-15. https://doi.org/10.14742/ajet.3246 